\title{
PENGARUH BOARD SIZE PADA NILAI PERUSAHAAN DENGAN MANAJEMEN LABA SEBAGAI VARIABEL INTERVENING
}

\author{
A.A Pt. Agung Mirah Purnama Sari ${ }^{1}$ \\ Ni Ketut Rasmini ${ }^{2}$ \\ I Gst. Ayu Nyoman Budiasih ${ }^{3}$ \\ ${ }^{1}$ Fakultas Ekonomi dan Bisnis Universitas Udayana, Bali, Indonesia \\ ${ }^{1}$ Email: agungputumirah@gmail.com \\ ${ }^{2}$ Fakultas Ekonomi dan Bisnis Universitas Udayana, Bali, Indonesia \\ ${ }^{3}$ Fakultas Ekonomi dan Bisnis Universitas Udayana, Bali, Indonesia
}

\begin{abstract}
ABSTRAK
Penelitian ini menguji pengaruh board size pada nilai perusahaan dengan manajemen laba sebagai variabel intervening. Data penelitian dikumpulkan dari seluruh perusahaan manufaktur yang terdaftar di Bursa Efek Indonesia pada periode tahun 2012 - 2015 sejumlah 150 perusahaan. Sampel diperoleh dengan menggunakan metode stratified random sampling dan menghasilkan sampel sejumlah 84 perusahaan. Teknik analisis data yang digunakan dalam penelitian ini adalah path anlysis. Berdasarkan hasil pengujian empiris dan pembahasan dapat disimpulkan bahwa variabel board size, dewan direksi, dewan komisaris independen dan dewan komisaris non independen berpengaruh positif pada nilai perusahaan. Variabel board size dan dewan direksi berpengaruh positif pada manajemen laba. Sedangkan, variabel dewan komisaris independen dan dewan komisaris non independen berpengaruh negatif pada manajemen laba. Variabel manajemen laba berpengaruh negatif pada nilai perusahaan dan hasil pengujian mediasi menunjukkan bahwa manajemen laba tidak mampu memediasi hubungan board size dengan nilai perusahaan.
\end{abstract}

Kata kunci: board size, nilai perusahaan, manajemen laba

\begin{abstract}
This study aims to examined the effect of board size on firm value by using earnings management as an intervening variable. Data were collected from 150 manufacturing companies listed in Indonesia Stock Exchange in the period 2012 - 2015. 84 samples were selected using stratified random sampling method. Data analysis techniques used in this study was the path anlysis. Based on empirical test results can be concluded that board size, board of directors, board of independent commissioner, and board of non independent commissioner has positive effect on firm value. Variable of board size and board of directors has positive effect on earnings management. Meanwhile, board of independent commissioner and board of non independent commissioner has negative effect on earnings management. Variable earnings management negatively affect firm value and the mediation test results show that earnings management is not able to mediate the association between board size with the firm value.
\end{abstract}

Keywords: board size, firm value, earnings management 
A.A Pt. Agung Mirah Purnama Sari, Ni Ketut Rasmini dan I Gst Ayu Nyoman Budiasih., Pengaruh....

\section{PENDAHULUAN}

Salah satu tujuan perusahaan adalah untuk memaksimalkan nilai perusahaan yang tercermin pada nilai pasar saham perusahaan. Nilai pasar saham yang semakin tinggi menunjukkan semakin meningkatnya nilai perusahaan. Hal ini digunakan sebagai pengukur keberhasilan perusahaan karena dengan tingginya nilai perusahaan berarti kemakmuran pemegang saham perusahaan juga semakin tinggi (Martono, 2010). Salah satu tujuan perusahaan adalah untuk memaksimalkan nilai perusahaan yang tercermin pada nilai pasar saham perusahaan. Nilai pasar saham yang semakin tinggi menunjukkan semakin meningkatnya nilai perusahaan. Hal ini digunakan sebagai pengukur keberhasilan perusahaan karena dengan tingginya nilai perusahaan berarti kemakmuran pemegang saham perusahaan juga semakin tinggi (Martono, 2010).

Pasar modal Indonesia yang didalamnya mayoritas perusahaan manufaktur dikategorikan sebagai pasar modal yang sedang tumbuh memiliki kontribusi besar dalam ekonomi Indonesia. Pada umumnya perusahaan yang berjalan dengan baik memiliki rasio Price to Book Value (PBV) di atas satu, yang menunjukkan bahwa nilai pasar saham lebih besar daripada nilai bukunya. Semakin tingginya nilai PBV menunjukkan semakin tingginya perusahaan dinilai oleh investor (Wardjono, 2010). Namun, pada perusahaan manufaktur yang terdaftar di Bursa Efek Indonesia masih ada beberapa perusahaan yang memiliki rasio PBV dibawah satu. Rasio PBV digunakan untuk mengukur kinerja keuangan perusahaan dan rasio ini juga digunakan untuk mengukur nilai yang diberikan pasar keuangan kepada manajemen dan organisasi sebagai perusahaan yang terus tumbuh. Rasio PBV yang semakin tinggi menunjukkan bahwa semakin berhasil perusahaan 
menciptakan nilai bagi pemegang saham. Nilai buku menjadi ukuran rasional untuk menilai perusahaan. Oleh sebab itu, rasio PBV dapat digunakan untuk semua jenis perusahaan (Reilly, 2000).

Proses pengambilan keputusan pendanaan, kebijakan dividen dan keputusan investasi dilakukan oleh manajemen baik pada organisasi publik atau bisnis menggunakan konsep tata kelola perusahaan. Tata kelola perusahaan diterapkan secara formal di Indonesia dengan diterbitkannya "Pedoman umum Good Corporate Governance" oleh Komite Nasional Kebijakan Governance (KNKG). Corporate Governance memiliki struktur yang merupakan gambaran dan berguna dalam menentukan arahan strategis, kinerja sistematis dan pengawasan kinerja perusahaan. Struktur didefinisikan sebagai satu cara bagaimana aktivitas dalam organisasi dibagi, diorganisir dan dikoordinasi (Stoner et al., 1996). Model struktur internal corporate governance secara umum terbagi menjadi 2 (dua), yaitu The Anglo-American System dan The Continental Europe System. Anglo-American System atau Single-board System tidak memisahkan keanggotaan dewan komisaris dan dewan direksi. Sehingga kedua dewan tersebut sama-sama disebut sebagai board of directors. Anglo-American System memiliki struktur pemerintahan yang terdiri dari executive managers yang dipimpin oleh CEO, Board of Directors (executive directors non-executive directors, dan RUPS (Rapat Umum Pemegang Saham).

Pada two-board system, dewan direksi dan dewan komisaris memiliki tanggung jawab dan wewenang yang jelas sesuai dengan fungsinya masing-masing yang terangkum pada peraturan perundang-undangan yang berlaku. Two-board system diterapkan pada kepengurusan Perseroan Terbatas di Indonesia. Namun 
A.A Pt. Agung Mirah Purnama Sari, Ni Ketut Rasmini dan I Gst Ayu Nyoman Budiasih., Pengaruh....

terdapat perbedaan antara two-board system yang diterapkan di Indonesia dengan The Continental Europe System. Perseroan Terbatas di Indonesia menempatkan wewenang pengangkatan dan pemberhentian direksi berada di tangan RUPS. Kesejajaran antara kedudukan dewan direksi dan dewan komisaris pada kepengurusan Perseroan Terbatas di Indonesia diatur dalam Undang-Undang No. 40 Tahun 2007 tentang Perseroan Terbatas.

Pada two-board system, kegiatan operasional perusahaan merupakan tanggung jawab direksi sedangkan komisaris bertindak sebagai pengawas perusahaan. Konflik kepentingan juga kerap terjadi pada keduanya walaupun kedua dewan ini memiliki tanggung jawab penuh pada keberlangsungan perusahaan yang sesuai dengan tujuan dari perusahaan itu sendiri. Dewan komisaris memiliki posisi hukum yang lebih kuat dari dewan direksi. Namun, dewan komisaris cenderung memiliki akses yang sangat minim terhadap informasi perusahaan. Oleh karena itu, instrumen laporan keuangan digunakan sebagai solusi dalam konflik kepentingan antara keduanya.

Laporan keuangan digunakan sebagai tujuan untuk menilai kinerja dari dewan direksi. Laporan keuangan dimanipulasi dengan menggunakan metode khusus oleh dewan direksi yang biasa disebut dengan earnings management. Praktik earnings management bukan praktik berbahaya melainkan hal ini dilakukan berdasarkan pada keyakinan bahwa dewan direksi harus menyajikan laporan keuangan yang baik dengan catatan yang baik pula di setiap periodenya (Nugroho, 2011). Selain itu, praktik manajemen laba bisa terjadi karena investor itu sendiri dengan cara menambahkan modalnya kepada suatu perusahaan apabila kinerja perusahaan itu bagus yang ditunjukkan dengan laporan keuangan. Indikator laba 
dinilai sangat penting oleh investor sehingga dapat memicu terjadinya manajemen laba oleh dewan direksi.

Kinerja perusahaan dinilai melalui laporan keuangan perusahaan sehingga dapat mempengaruhi nilai perusahaan. Adanya perbedaan kepentingan atau pemisahan peran antara pengelola/manajemen perusahaan (agent) dengan pemegang saham (principal) merupakan pemicu dari masalah keagenan yang ditimbulkan oleh manajemen laba (Herawaty, 2009). Teori yang digunakan dalam penelitian ini adalah agency theory. Agency theory atau teori keagenan adalah sebuah kontrak antara pemilik (principal) dengan manajer (agent). Perspektif agency theory juga digunakan sebagai dasar untuk memahami corporate governance.

Perusahaan manufaktur di Indonesia cenderung memiliki anggota dewan yang relatif besar yaitu lebih dari 7 orang. Besarnya anggota dewan pada perusahaan manufaktur di Indonesia akan berindikasi pada rawan terjadinya asimetri informasi diantara dewan direksi dengan dewan komisaris. Berdasarkan pemikiran tersebut, penting untuk memasukkan variabel intervening yaitu manajemen laba pada penelitian ini dan melihat pengaruh yang dihasilkan dari digunakannya variabel manajemen laba ini sebagai variabel perantara. Penelitian ini menggunakan Discretionary Accruals (DA) sebagai proksi dari earnings management karena DA merupakan akrual yang dapat diatur oleh seorang manajer dan akan berakibat dalam pengelolaan laba suatu perusahaan. Pengukuran DA dilakukan dengan menggunakan modified jones model. Manajemen laba dapat dieliminasi tidak hanya dengan dewan komisaris tetapi keberadaan komite audit juga dapat membantu mengeliminasi terjadinya earnings management. Manajemen 
A.A Pt. Agung Mirah Purnama Sari, Ni Ketut Rasmini dan I Gst Ayu Nyoman Budiasih., Pengaruh....

laba merupakan masalah keagenan yang terjadi pada dewan komisaris dan dewan direksi yang dapat diminimalisasi dengan pengurangan perataan pendapatan, penekanan biaya keagenan, efisiensi arus kas perusahaan, atau perbaikan kinerja perusahaan (Ghosh, 2010).

Praktik manajemen laba dalam suatu perusahaan juga dapat terjadi karena laba yang dihasilkan perusahaan selama tahun berjalan. Laba atau profitabilitas merupakan suatu indikator kinerja manajemen dalam mengelola kekayaan perusahaan yang ditunjukkan oleh laba yang dihasilkan perusahaan. Biasanya manajemen laba dilakukan oleh manajer untuk memanipulasi komponen laba rugi yang dilaporkan perusahaan (Sudarmadji dkk., 2007). Rasio profitabilitas menunjukkan bahwa seberapa besar kemampuan perusahaan untuk menghasilkan keuntungan bagi perusahaan (Hidayati, 2010). Rasio profitabilitas pada penelitian ini diproksikan dengan menggunakan Return on Equity (ROE). ROE yang tinggi mengakibatkan tingginya harga saham sehingga membawa keberhasilan bagi perusahaan. Selain itu, angka ROE yang tinggi juga mampu membuat perusahaan menjadi lebih berkembang, mampu menarik dana baru, menciptakan kondisi pasar yang sesuai, hingga memberikan laba yang lebih besar bagi perusahaan (Walsh, 1996). Selain ROE, usia perusahaan juga memiliki dampak pada nilai perusahaan. Perusahaan yang telah lama berdiri mengalami pertumbuhan yang lambat sehingga investor tidak tertarik berinvestasi dan membuat nilai perusahaan menurun (Hariyanto, 2014).

Nilai perusahaan juga akan meningkat jika hutang digunakan secara efektif dan efisien. Namun, apabila penggunaan hutang digunakan sebagai alasan untuk menarik kreditur maka praktik manajemen laba di dalam perusahaan tidak dapat 
dihindari. Struktur pendanaan diproksikan dengan Debt to Equity Ratio (DER) yang menunjukkan seberapa besar aset yang dimiliki perusahaan yang dibiayai dengan hutang. DER menunjukkan risiko yang dihadapi perusahaan. Ketidakpastian peningkatan laba masa depan disebabkan apabila semakin besar risiko yang dihadapi perusahaan. Keuntungan yang mungkin bisa diperoleh investor dapat diprediksi melalui hutang. Hal ini menunjukkan bahwa rasio hutang memiliki hubungan dengan return perusahaan (Foster, 1986). Selain itu, keberadaan hutang juga mampu mempengaruhi manajemen untuk melakukan manajemen laba. Agency theory menyebutkan bahwa semakin dekat perusahaan dengan pelanggaran perjanjian utang yang berbasis akuntansi maka lebih memungkinkan manajer perusahaan untuk memilih prosedur akuntansi yang memindahkan laba yang dilaporkan dari periode masa datang ke periode saat ini (Watts and Zimmerman, 1986).

Penelitian ini menggunakan objek perusahaan manufaktur dengan rentang waktu penelitian selama empat tahun (2012 - 2015). Alasan digunakannya rentang waktu penelitian tersebut agar didapatkan data terbaru sehingga hasil penelitian yang dihasilkan akan menjadi lebih relevan dan sesuai dengan keadaan saat ini. Perusahaan manufaktur merupakan cerminan pasar modal secara keseluruhan dan terdiri dari berbagai sub sektor industri. Selain itu, kasus yang melibatkan perusahaan manufaktur lebih banyak mendominasi dibandingkan dengan perusahaan lainnya. Perusahaan manufaktur menjual produknya dimulai dari proses produksi hingga menjadi produk jadi yang bisa dijual. Hal ini tentu saja akan membutuhkan dana jangka panjang untuk membiayai operasional perusahaan salah 
A.A Pt. Agung Mirah Purnama Sari, Ni Ketut Rasmini dan I Gst Ayu Nyoman Budiasih., Pengaruh....

satunya adalah dengan investasi saham oleh para investor yang dilihat dari nilai perusahaan (Hermansyah, 2012).

Penelitian ini bertujuan untuk memperoleh bukti empiris pengaruh board size yang diproksikan dengan dengan dewan direksi, dewan komisaris independen dan dewan komisaris non independen pada nilai perusahaan dengan manajemen laba sebagai variabel intervening. Kemampuan individu (baik agent maupun principal) dalam mengevaluasi lingkungan dimana keputusan harus diambil dan kemampuan untuk mengevaluasi hasil dari keputusan yang telah diambil guna mempermudah pengalokasian hasil antara agent dan principal sesuai dengan kontrak kerja diharapkan meningkat melalui penelitian ini. Penelitian ini juga dapat dijadikan dasar pertimbangan dalam membuat keputusan investasi pada perusahaan yang terdaftar di BEI dan sebagai bahan masukan dalam upaya meningkatkan nilai perusahaan terhadap board size dan manajemen laba.

Pada penelitian ini, board size (ukuran dewan) terdiri dari dewan direksi, dewan komisaris independen dan dewan komisaris non independen. Dewan direksi bertugas untuk menjalankan manajemen perusahaan. Oleh karena itu, keberadaan dewan direksi penting untuk keberlangsungan perusahaan demi meningkatkan nilai perusahaan. Peningkatan nilai perusahaan juga dapat dipengaruhi oleh keberadaan dewan komisaris independen. Jumlah dewan komisaris independen yang besar dapat meningkatkan kontrol pada perusahaan sehingga meningkatkan kepercayaan investor. Pengaruh board size pada nilai perusahaan yang dilakukan oleh Sukanto (2015) memperoleh hasil positif antara ukuran dewan komisaris pada nilai pasar perusahaan. Pengaruh positif antara ukuran dewan pada nilai perusahaan juga diperoleh dari penelitian yang dilakukan oleh Mat Nor dan Sulong (2008). Ukuran 
dewan yang tinggi dapat meningkatkan monitoring pada kebijakan pemerintah yang berpengaruh pada perusahaan, nilai dividen, dan kepemilikan asing dalam mengurangi agency cost, dimana hal-hal tersebut dapat meningkatkan nilai perusahaan.

$\mathrm{H}_{1}$ : Board size berpengaruh positif pada nilai perusahaan.

Isshaq et al. (2009) menunjukkan bahwa ukuran dewan direksi yang besar digunakan oleh perusahaan sebagai alat untuk menyamakan kepentingan anggota dewan direksi dengan manajer. Sehingga akan meningkatkan nilai perusahaan dan selanjutnya akan meningkatkan tingkat kepentingan manajer untuk terus meningkatkan nilai perusahaan. Besarnya ukuran dewan direksi pada penyesuaian kondisi perusahaan akan berdampak baik dalam hal meningkatkan nilai perusahaan karena dengan demikian direksi akan menggunakan kekuasaannya untuk menekankan ke manajerial (Chaganti, 1985).

$\mathrm{H}_{1 \mathrm{a}}$ : Jumlah dewan direksi berpengaruh positif pada nilai perusahaan

Choi et al. (2007) menemukan bahwa pengaruh direktur independen pada kinerja perusahaan adalah positif. Choi et al. (2007) juga menemukan hubungan negatif antara proporsi direktur independen pada transaksi dengan pihak terkait dan dewan. Selain itu, Dahya et al. (2007) melakukan analisis pada 799 perusahaan di 22 negara menemukan bahwa hubungan positif dari proporsi direktur independen pada kinerja perusahaan di hadapan pemegang saham dominan dan negara-negara dengan lemahnya perlindungan hak pemegang saham. Hasil sebaliknya diperoleh oleh Trisnantari (2010) yang menyatakan bahwa corporate governance yang diproksikan dengan kepemilikan institusional, kepemilikan manajerial, jumlah 
A.A Pt. Agung Mirah Purnama Sari, Ni Ketut Rasmini dan I Gst Ayu Nyoman Budiasih., Pengaruh....

anggota komite audit, dan proporsi dewan komisaris independen berpengaruh positif pada kinerja perusahaan.

$\mathrm{H}_{1 \mathrm{~b}}$ : Jumlah dewan komisaris independen berpengaruh positif pada nilai perusahaan

Efektivitas corporate board yang semakin tinggi disebabkan oleh semakin besarnya jumlah dewan komisaris sehingga berdampak pada meningkatnya kinerja perusahaan (Banhart dan Rosenstein, 1998). Servis dan kontrol yang dilakukan oleh dewan komisaris dapat meningkatkan kinerja perusahaan. Sehingga disimpulkan bahwa jumlah dewan komisaris berhubungan positif pada nilai perusahaan (Kusumawati dan Riyanti, 2005). Jumlah dewan komisaris yang besar dipandang sebagai sarana untuk mengontrol dan memberi masukan pada perilaku oportunistik manajemen dan direksi (Kusumawati dan Riyanti, 2005).

$\mathrm{H}_{1 \mathrm{c}}$ : Jumlah dewan komisaris non independen berpengaruh positif pada nilai perusahaan

Dewan komisaris pada suatu perusahaan yang didominasi oleh manajemen biasanya memiliki kemungkinan yang lebih besar dalam melakukan manipulasi laba. Kemungkinan terjadinya praktik manipulasi laba juga disebabkan oleh kepemilikan CEO yang merangkap sebagai Chairman of the Board (Dechow et al., 1996). Jumlah dewan yang besar berdampak pada meningkatnya permasalahan dalam hal komunikasi dan koordinasi.

Permasalahan keagenan dari pemisahan tugas antara pengawas dan manajemen ditimbulkan dari meningkatnya jumlah dewan dan kemampuan dewan dalam mengendalikan manajemen yang semakin menurun. Permasalahan tersebut mengakibatkan manajemen laba yang semakin meningkat karena corporate 
governance yang buruk sehingga mempengaruhi kinerja perusahaan. (Yermack, 1996).

$\mathrm{H}_{2}$ : $\quad$ Manajemen laba memediasi pengaruh antara board size yang diproksikan dengan dewan direksi, dewan komisaris independen dan dewan komisaris non independen pada nilai perusahaan.

Secara umum, dewan komisaris ditugaskan sebagai pengawas kualitas informasi yang ada pada laporan keuangan. Laporan keuangan atau informasi pada suatu perusahaan diperbolehkan untuk diakses oleh dewan komisaris. Hal ini penting untuk dilakukan sebab pihak manajemen memiliki kepentingan untuk melakukan earnings management yang berdampak pada berkurangnya kepercayaan investor. Dewan direksi memiliki tanggung jawab untuk menyampaikan informasi yang terkait dengan perusahaan kepada dewan komisaris. Hal ini harus dilakukan karena dewan komisaris tidak memiliki otoritas dalam perusahaan. Tanggung jawab dewan direksi lainnya adalah menentukan kebijakan yang akan dijalankan oleh perusahaan, baik dalam jangka waktu panjang maupun jangka pendek. Selain itu, manajemen laba mampu diatasi salah satunya dengan besaran ukuran dewan direksi yang merupakan salah satu komponen dari good corporate governance.

$\mathrm{H}_{3}$ : $\quad$ Board size berpengaruh negatif pada manajemen laba

Kebijakan yang akan dijalankan oleh perusahaan baik kebijakan jangka panjang atau kebijakan jangka pendek merupakan salah satu peran penting dewan direksi. Besarnya hubungan eksternal yang efektif akan mempengaruhi meningkatnya kebutuhan akan dewan dalam jumlah besar (Preffer \& Salancik, 1978). Iqbal dan Fachriyah (2008) menyatakan keberadaan earnings management dapat ditekan dengan adanya jumlah dewan direksi yang besar. 
A.A Pt. Agung Mirah Purnama Sari, Ni Ketut Rasmini dan I Gst Ayu Nyoman Budiasih., Pengaruh....

$\mathrm{H}_{3 a}: \quad$ Dewan direksi berpengaruh negatif pada manajemen laba

Dewan komisaris yang merupakan puncak dari sistem pengelolaan internal perusahaan memiliki peran penting dalam pelaksanaan good corporate governance. Dewan komisaris bertugas mengawasi manajemen dalam pengelolaan perusahaan, menjamin pelaksanaan strategi perusahaan, serta mewajibkan terlaksananya akuntabilitas (Egon, 2000).

Dewan komisaris independen merupakan pihak eksternal perusahaan yang tidak berkaitan langsung dengan perusahaan yang ditangani. Dewan komisaris independen bertugas untuk memonitoring dewan direksi perusahaan tanpa ada tekanan dari pihak manapun.

Keberadaan dewan komisaris independen akan mendorong pengambilan keputusan untuk melakukan perubahan. Hal ini dilakukan apabila ada resistensi dari CEO untuk menerapkan strategi yang agresif dalam mengatasi kinerja perusahaan yang terus menurun (Dalton dan Daily, 1999).

$\mathrm{H}_{3 \mathrm{~b}}$ : Dewan komisaris independen berpengaruh negatif pada manajemen laba.

Keberadaan dewan komisaris dapat meminimalisasi terjadinya praktik manajemen laba dalam perusahaan perbankan. Jumlah personel dewan komisaris non independen yang lebih sedikit lebih efektif dalam menghambat terjadinya masalah keagenan sehingga dapat menekan terjadinya praktik manajemen laba (Nasution dan Setiawan, 2007). Nasution dan Setiawan (2007) juga menyatakan bahwa munculnya masalah keagenan akan berdampak pada berkurangnya pengawasan dewan komisaris independen pada pihak manajemen untuk melakukan manajemen laba.

$\mathrm{H}_{3 \mathrm{c}}$ : Dewan komisaris non independen berpengaruh negatif pada manajemen laba. 
Praktik manajemen laba adalah mengenai pilihan kebijakan akuntansi yang digunakan dalam penyusunan laporan keuangan. Praktik ini bukannlah hal yang buruk apabila dilakukan masih dalam batasan prinsip-prinsip akuntansi untuk memperoleh tingkat pendapatan yang diinginkan. Informasi dalam laporan keuangan akan mempengaruhi nilai perusahaan karena laporan keuangan seringkali dijadikan dasar untuk penilaian kinerja perusahaan. Informasi dalam laporan keuangan yang sering digunakan salah satunya adalah informasi laba. Hal ini dikarenakan informasi laba pada laporan keuangan memiliki nilai prediktif.

$\mathrm{H}_{4}$ : Manajemen laba berpengaruh positif pada nilai perusahaan.

\section{METODE PENELITIAN}

Penelitian ini dilakukan pada perusahaan manufaktur yang terdaftar di Bursa Efek Indonesia tahun 2012 - 2015 dengan mengakses www.idx.co.id. Populasi penelitian ini adalah perusahaan manufaktur yang terdaftar di Bursa Efek Indonesia tahun 2012-2015 dengan melakukan akses pada website www.idx.co.id sehingga diperoleh populasi berjumlah 150 perusahaan. Adapun teknik pengambilan sampel yang digunakan adalah probability sampling jenis stratified random sampling. Probability sampling adalah teknik pengambilan sampel yang memberikan peluang yang sama bagi setiap unsur (anggota) populasi untuk dipilih menjadi anggota sampel. Stratified random sampling adalah sampel yang ditarik dengan memisahkan elemen-elemen populasi dalam kelompok-kelompok yang tidak overlapping yang disebut strata, dan kemudian memilih sebuah sampel secara random dari tiap stratum (Nazir, 2011:291). Sampel diperoleh secara random dengan teknik undian sehingga setiap anggota 
A.A Pt. Agung Mirah Purnama Sari, Ni Ketut Rasmini dan I Gst Ayu Nyoman Budiasih., Pengaruh....

populasi memiliki peluang yang sama untuk menjadi sampel penelitian. Berdasarkan jumlah populasi tersebut dengan tingkat kelonggaran ketidaktelitian sebesar 5\%, maka dengan menggunakan rumus Slovin diperoleh sampel sebesar:

$$
\mathrm{n}=\frac{150}{1+150(0,05)^{2}}=\frac{150}{1,375}=109,09=109
$$

Berdasarkan hasil perhitungan menggunakan rumus slovin, diperoleh sampel berjumlah 109 perusahaan. Namun sebanyak 25 perusahaan manufaktur dikeluarkan dari sampel karena menggunakan kurs dollar dalam laporan keuangannya sehingga sampel yang memenuhi syarat untuk digunakan dalam penelitian adalah sebanyak 84 perusahaan (Tabel 2).

Penelitian ini menggunakan variabel dependen, variabel independen, variabel intervening dan variabel kontrol. Variabel dependen yang digunakan adalah nilai perusahaan dan diukur dengan menggunakan Price to Book Value (PBV) yang merupakan rasio antara harga perlembar saham dengan nilai buku perlembar saham pada perusahaan manufaktur di BEI. Variabel independen yang digunakan adalah board size dan diukur dengan dengan menggunakan total jumlah personel dalam dewan komisaris ditambah dengan jumlah personel dari dewan direksi dalam suatu perusahaan. Informasi mengenai jumlah dewan komisaris dan jumlah dari dewan direksi diperoleh dari Laporan Tahunan perusahaan. Penelitian ini juga menggunakan variabel intervening yaitu manajemen laba. Manajemen laba diukur dengan menggunakan proksi discretionary accruals dan dihitung dengan menggunakan Modified Jones Model. 
Tabel 1.

Metode Pengambilan Sampel dengan Rumus Slovin

\begin{tabular}{|c|c|c|}
\hline Nama Perusahaan & Rumus & $\begin{array}{l}\text { Pengambilan } \\
\text { Sampel }\end{array}$ \\
\hline \multicolumn{3}{|l|}{ Basic Industry and Chemicals } \\
\hline 1. $\quad$ Cement & $\frac{5}{150} \times 109=3,63$ & $3 *$ \\
\hline 2. Ceramics, Glass, Porcelain & $\frac{6}{150} \times 109=4,36$ & 5 \\
\hline 3. Metal and Allied Products & $\frac{16}{150} \times 109=11,63$ & 13 \\
\hline 4. Chemicals & $\frac{10}{150} \times 109=7,27$ & 7 \\
\hline 5. $\quad$ Plastic and Packaging & $\frac{13}{150} \times 109=9,45$ & 9 \\
\hline 6. Animal Feed & $\frac{4}{150} \times 109=2,91$ & 3 \\
\hline 7. $\quad$ Wood Industries & $\frac{2}{150} \times 109=1,45$ & 2 \\
\hline 8. $\quad$ Pulp and Paper & $\frac{10}{150} \times 109=7,26$ & 7 \\
\hline 9. $\quad$ Miscellaneous Industry & $\frac{1}{150} \times 109=0,73$ & 1 \\
\hline 10. Machinery and Heavy Equipment & $\frac{1}{150} \times 109=0,73$ & $0 *$ \\
\hline 11. Automotive and Components & $\frac{13}{150} \times 109=9,45$ & 9 \\
\hline 12. Textile, Garment & $\frac{20}{150} \times 109=14,53$ & 15 \\
\hline 13. Footwear & $\frac{2}{150} \times 109=1,45$ & 1 \\
\hline 14. Cable & $\frac{6}{150} \times 109=4,36$ & 4 \\
\hline 15. $\quad$ Electronics & $\frac{1}{150} \times 109=0,73$ & 1 \\
\hline \multicolumn{3}{|l|}{ Consumer and Good Industry } \\
\hline 16. $\quad$ Food and Beverages & $\frac{16}{150} \times 109=11,63$ & 12 \\
\hline 17. Tobacco Manufactures & $\frac{4}{150} \times 109=2,91$ & 3 \\
\hline 18. Pharmaceuticals & $\frac{10}{150} \times 109=7,27$ & 8 \\
\hline 19. Cosmetics and Household & $\frac{6}{150} \times 109=4,36$ & 4 \\
\hline 20. Houseware & $\frac{4}{150} \times 109=2,91$ & $2 *$ \\
\hline Jumlah Sampel & & 109 \\
\hline
\end{tabular}




\section{Tabel 2.}

\section{Metode Penentuan Jumlah Sampel Akhir}

\begin{tabular}{lc}
\hline Sampel Perusahaan awal & 109 perusahaan manufaktur \\
\hline $\begin{array}{l}\text { (-) Perusahaan yang menggunakan dollar } \\
\text { dalam laporan keuangannya }\end{array}$ & 25 perusahaan manufaktur \\
\hline Total sampel akhir & 84 perusahaan manufaktur \\
\hline
\end{tabular}

Sumber: data diolah (2017)

Penelitian yang dihasilkan oleh Dechow et al. (1995) menyatakan bahwa versi modifikasi yang dikembangkan oleh Jones (1991) menunjukkan keakuratan yang lebih baik dalam mendeteksi manajemen laba. Selain itu, penelitian ini juga menggunakan variabel kontrol yaitu struktur pendanaan, profitabilitas, usia perusahaan dan komite audit. Variabel kontrol digunakan dengan tujuan agar pengaruh ariabel bebas pada variabel terikat tidak dipengaruhi oleh faktor luar yang tidak diteliti. Struktur pendanaan diukur dengan menggunakan Debt To Equity Ratio (DER) yang merupakan perbandingan total utang perusahaan dengan total ekuitas perusahaan pada perusahaan manufaktur di BEI (Kusumajaya, 2011). Profitabilitas diukur dengan menggunakan Return on Equity (ROE). ROE digunakan untuk mengukur kemampuan perusahaan memperoleh laba yang tersedia bagi pemegang saham perusahaan (Sartono, 2001). Usia perusahaan diukur berdasarkan selisih antara tanggal periode pengamatan dengan tanggal pendirian perusahaan yang terdaftar di Bursa Efek Indonesia. Sedangkan, Komite audit diukur dengan melihat jumlah personel dalam komite audit pada suatu perusahaan yang diperoleh dari Laporan Tahunan perusahaan.

Data dianalisis dengan menggunakan statistik deskriptif, analisis jalur, uji sobel, uji asumsi klasik dan pengujian hipotesis. Model analisis jalur digunakan 
untuk menguji pengaruh variabel intervening. Variabel intervening merupakan variabel antara atau mediating, fungsinya memediasi antara variabel independen dengan variabel dependen. Suatu variabel disebut variabel intervening jika variabel tersebut ikut mempengaruhi hubungan antara variabel independen dan variabel dependen. Pengujian hipotesis mediasi dapat dilakukan dengan prosedur yang dikembangkan oleh Sobel (1982) dan dikenal dengan Uji Sobel (Sobel Test) (Baron dan Kenny, 1986). Uji Sobel dilakukan dengan cara menguji kekuatan pengaruh tidak langsung variabel (X) ke variabel (Y) melalui variabel (M). Pengaruh tidak langsung $\mathrm{X}$ ke $\mathrm{Y}$ melalui $\mathrm{M}$ dihitung dengan cara mengalikan jalur $\mathrm{X} \rightarrow \mathrm{M}(\mathbf{a})$ dengan jalur $\mathrm{M} \rightarrow \mathrm{Y}(\mathbf{b})$ atau ab. Jadi koefisien $\mathbf{a b}=\left(\mathbf{c}-\mathbf{c}^{\prime}\right)$, di mana $\mathbf{c}$ adalah pengaruh $\mathrm{X}$ terhadap $\mathrm{Y}$ tanpa

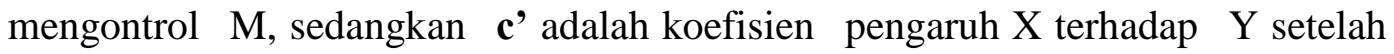
mengontrol M. Standard error koefisien a dan b ditulis dengan Sa dan Sb, besarnya standard error pengaruh tidak langsung (indirect effect) Sab dihitung dengan rumus sebagai berikut:

$$
\mathrm{Sab}=\sqrt{b^{2} s a^{2}+a^{2} s b^{2}+s a^{2} s b^{2}}
$$

Untuk menguji signifikansi pengaruh tidak langsung, maka perlu menghitung nilai $\mathrm{t}$ dari koefisien ab dengan rumus sebagai berikut:

$$
\frac{a b}{s a b}
$$

Nilai $\mathrm{t}$ hitung ini dibandingkan dengan nilai $\mathrm{t}$ Tabel yaitu $\geq 1,96$. Jika nilai $\mathrm{t}$ hitung lebih besar dari nilai t Tabel maka dapat disimpulkan terjadi pengaruh langsung (Ghozali, 2012).

Pengujian regresi linier berganda dan analisis jalur dapat dilakukan setelah model dari penelitian memenuhi syarat untuk lolos dari uji asumsi klasik. 
A.A Pt. Agung Mirah Purnama Sari, Ni Ketut Rasmini dan I Gst Ayu Nyoman Budiasih., Pengaruh....

Analisis jalur adalah perluasan dari regresi linier berganda sehingga penting untuk dilakukan pengujian asumsi klasik terlebih dahulu sebelum dilanjutkan ke analisis jalur. Asumsi klasik adalah suatu pengujian hipotesis yang digunakan dalam suatu penelitian yang menunjukkan bahwa model regresi tersebut layak atau tidak untuk dilakukan ke pengujian selanjutnya (Ghozali, 2006). Syarat-syarat yang harus dipenuhi adalah residual data yang diteliti harus terdistribusikan secara normal, tidak mengandung multikoliniaritas, autokorelasi dan heteroskedastisitas.

Hipotesis penelitian ini diuji dengan pengujian satu sisi. Dengan demikian, output regresi yang dihasilkan oleh software statistik tersebut harus disesuaikan berdasarkan Tabel 3 .

Tabel 3.

Pengujian Hipotesis

\begin{tabular}{|c|c|c|}
\hline \multirow[t]{2}{*}{ Pengujian Hipotesis } & \multicolumn{2}{|c|}{ Tanda Koefisien Regresi Variabel } \\
\hline & $(+)$ & $(-)$ \\
\hline Uji sisi kanan & P-Value ${ }^{*}=\frac{P-\text { Value }}{2}$ & $\mathrm{P}-$ Value $^{*}=1-\left[\frac{P-\text { Value }}{2}\right]$ \\
\hline Uji sisi kiri & $\mathrm{P}-$ Value $^{*}=1-\left[\frac{P-\text { Value }}{2}\right]$ & $\mathrm{P}-$ Value $^{*}=\frac{P-\text { Value }}{2}$ \\
\hline
\end{tabular}

Sumber: Studenmund (2006)

\section{HASIL DAN PEMBAHASAN}

Statistik deskriptif mengenai variabel board size, dewan direksi, dewan komisaris independen, dewan komisaris non independen, manajemen laba dan nilai perusahaan pada perusahaan sampel dijelaskan pada Tabel 4. Sedangkan Statistik deskriptif mengenai variabel kontrol penelitian pada perusahaan sampel dapat dijelaskan pada Tabel 5. 
ISSN: 2337-3067

E-Jurnal Ekonomi dan Bisnis Universitas Udayana 7.10(2018):2217-2246

Tabel 4.

Statistik Deskriptif Variabel Penelitian Perusahaan Sampel

\begin{tabular}{lcccccc}
\hline & $\begin{array}{c}\text { Board } \\
\text { Size }\end{array}$ & $\begin{array}{c}\text { Dewan } \\
\text { Direksi }\end{array}$ & $\begin{array}{c}\text { Dewan } \\
\text { Komisaris } \\
\text { Independen }\end{array}$ & $\begin{array}{c}\text { Dewan } \\
\text { Komisaris } \\
\text { Non } \\
\text { independen }\end{array}$ & $\begin{array}{c}\text { Manajemen } \\
\text { Laba }\end{array}$ & $\begin{array}{c}\text { Nilai } \\
\text { Perusahaan }\end{array}$ \\
\hline Mean & 9,08 & 4,98 & 1,70 & 2,40 & 0,0004 & 2,73 \\
\hline Max & 23 & 15 & 4 & 8 & 139,45 & 58,48 \\
\hline Min & 4 & 2 & 1 & 0 & $-23,51$ & $-108,76$ \\
\hline Std. Dev. & 4,07 & 2,64 & 0,87 & 1,26 & 10,34 & 9,34 \\
\hline Obs. & 336 & 336 & 336 & 336 & 336 & 336 \\
\hline
\end{tabular}

Sumber: data diolah (2017)

Tabel 5.

Statistik Deskriptif Variabel Kontrol Penelitian Perusahaan Sampel

\begin{tabular}{|c|c|c|c|c|}
\hline & $\begin{array}{c}\text { Struktur } \\
\text { Pendanaan }\end{array}$ & Profitabilitas & Usia Perusahaan & Komite Audit \\
\hline Mean & 1,17 & 11,34 & 37,75 & 3,07 \\
\hline Max & 70,83 & 207,09 & 115 & 5 \\
\hline Min & $-31,04$ & $-295,92$ & 3 & 1 \\
\hline Std. Dev. & 5,27 & 38,66 & 19,32 & 0,46 \\
\hline Obs. & 336 & 336 & 336 & 336 \\
\hline
\end{tabular}

Sumber: data diolah (2017) 
Tabel 6.

\section{Hasil Uji Normalitas, Multikolinieritas, Autokorelasi, dan} Heteroskedastisitas

\begin{tabular}{ccccc}
\hline Uraian & Normalitas & Multikolinieritas & Autokorelasi & Heteroskedastisitas \\
\cline { 2 - 5 } & P Value & VIF & Durbin Watson & Sig. \\
\hline $\mathrm{X}(\mathrm{BZ}) \rightarrow \mathrm{Y}(\mathrm{NP})$ & 0,000 & 1,163 & 1,918 & 0,752 \\
\hline $\begin{array}{c}\mathrm{X}_{1}(\mathrm{DD}), \mathrm{X}_{2}(\mathrm{DKI}), \mathrm{X}_{3} \\
(\mathrm{DKNI}) \rightarrow \mathrm{Y}(\mathrm{NP})\end{array}$ & 0,000 & $\begin{array}{c}\mathrm{DD}(1,687), \mathrm{DKI} \\
(1,981), \mathrm{DKNI} \\
(1,545)\end{array}$ & 1,965 & $\begin{array}{c}\text { DD }(0,890), \mathrm{DKI} \\
(0,477), \text { DKNI }(0,064)\end{array}$ \\
\hline $\mathrm{X}(\mathrm{BZ}) \rightarrow \mathrm{M}(\mathrm{MAN})$ & 0,000 & 1,163 & 1,950 & 0,075 \\
\hline $\begin{array}{c}\mathrm{X}_{1}(\mathrm{DD}), \mathrm{X}_{2}(\mathrm{DKI}), \mathrm{X}_{3} \\
(\mathrm{DKNI}) \rightarrow \mathrm{M}(\mathrm{MAN})\end{array}$ & 0,000 & $\begin{array}{c}\mathrm{DD}(1,687), \mathrm{DKI} \\
(1,981), \mathrm{DKNI} \\
(1,545)\end{array}$ & 1,966 & $\begin{array}{c}\mathrm{DD}(0,466), \mathrm{DKI} \\
(0,083), \mathrm{DKNI}(0,615)\end{array}$ \\
\hline $\mathrm{M}(\mathrm{MAN}) \rightarrow \mathrm{Y}(\mathrm{NP})$ & 0,000 & 1,036 & 1,968 & 0,454
\end{tabular}

Sumber: data diolah (2017)

Keterangan: BZ: Board Size. NP: Nilai Perusahaan. DD: Dewan Direksi. DKI: Dewan Komisaris Independen. DKNI: Dewan Komisaris Non Independen. MAN: Manajemen Laba.

Tabel 6 pada kolom normalitas menunjukkan bahwa nilai $\mathrm{P}$ - Value sebesar 0,000 lebih kecil dari level of significance $\alpha=0,05$, sehingga residual dinyatakan tidak berdistribusi normal tetapi residual model ini dapat dikatakan mendekati distribusi karena jumlah observasi yang dilakukan lebih dari 30 (Studenmund, 2006). Nilai multikolinieritas pada Tabel 6 menunjukkan bahwa nilai VIF lebih kecil dari 10. Oleh karena itu, disimpulkan bahwa tidak terjadi multikolinieritas pada penelitian ini. Hasil uji autokorelasi pada pengaruh board size pada nilai perusahaan dapat dilihat bahwa nilai durbin watson sebesar 1,918 dengan nilai $d_{L}=1,77$ dan $d_{u}=1,86\left(1,77<1,918<4-d_{u}(2,14)\right)$, Hasil uji autokorelasi pada pengaruh dewan direksi, dewan komisaris independen, dan dewan komisaris non independen pada nilai perusahaan dapat dilihat bahwa nilai durbin watson sebesar 1,965 dengan nilai $\mathrm{d}_{\mathrm{L}}=1,78$ dan $\mathrm{d}_{\mathrm{u}}=1,86(1,78<1,965<$ 4- $\left.\mathrm{d}_{\mathrm{u}}(2,14)\right)$, Hasil uji autokorelasi pada pengaruh board size pada manajemen laba 
dapat dilihat bahwa nilai durbin watson sebesar 1,950 dengan nilai $d_{L}=1,77$ dan $\mathrm{d}_{\mathrm{u}}=1,86\left(1,77<1,950<4-\mathrm{d}_{\mathrm{u}}(2,14)\right)$, Hasil uji autokorelasi pada pengaruh dewan direksi, dewan komisaris independen, dan dewan komisaris non independen pada manajemen laba dapat dilihat bahwa nilai durbin watson sebesar 1,966 dengan nilai $\mathrm{d}_{\mathrm{L}}=1,77$ dan $\mathrm{d}_{\mathrm{u}}=1,86\left(1,77<1,966<4-\mathrm{d}_{\mathrm{u}}(2,14)\right)$ dan hasil uji autokorelasi pada pengaruh manajemen laba pada nilai perusahaan dapat dilihat bahwa nilai durbin watson sebesar 1,968 dengan nilai $d_{L}=1,77$ dan $d_{u}=1,86$ $\left(1,77<1,968<4-d_{u}(2,14)\right)$. Dengan demikian d statistik berada pada daerah tidak ada autokorelasi atau model regresi yang dibuat tidak mengandung gejala autokorelasi, sehingga layak dipakai untuk memprediksi. Nilai yang dihasilkan dari uji heteroskedastisitas menunjukkan bahwa nilai signifikansi lebih besar dari 0,05. Dengan demikian dapat disimpulkan bahwa tidak terjadi masalah heteroskedastisitas pada model regresi.

Hasil pengujian hipotesis pengaruh board size pada nilai perusahaan dengan manajemen laba sebagai variabel intervening disajikan pada Tabel 7. Tabel 7 menunjukkan bahwa board size berpengaruh positif pada nilai perusahaan dengan koefisien regresi sebesar 0,412 dan signifikansi P-Value sebesar 0,000. Ini berarti bahwa semakin besar board size yang terdiri dari dewan direksi, dewan komisaris independen dan dewan komisaris non independen maka nilai perusahaan juga akan semakin tinggi secara signifikan. Hal ini berarti pertambahan 1 (satu) orang anggota dewan pada board size, baik itu pada dewan direksi, dewan komisaris independen dan dewan komisaris non independen dapat meningkatkan efektivitas pengambilan keputusan. Selain itu, 
A.A Pt. Agung Mirah Purnama Sari, Ni Ketut Rasmini dan I Gst Ayu Nyoman Budiasih., Pengaruh....

waktu yang digunakan dalam pengambilan keputusan dapat lebih efisien dan keputusan yang diambil memiliki kualitas yang lebih baik sehingga dapat menarik investor baru dan menyebabkan meningkatnya nilai perusahaan.

\section{Tabel 7.}

Hasil Pengujian Hipotesis

\begin{tabular}{|c|c|c|c|c|c|c|}
\hline Hipotesis & Uraian & $\begin{array}{l}\text { Koefisien } \\
\text { Regresi }\end{array}$ & $\begin{array}{l}\text { Standar Error } \\
\text { Koefisien } \\
\text { Regresi } \\
\end{array}$ & $\begin{array}{c}\mathrm{T}- \\
\text { Statistik }\end{array}$ & $\mathrm{P}$ Value & Keterangan \\
\hline $\mathrm{H}_{1}$ & $\mathrm{X}(\mathrm{BZ}) \rightarrow \mathrm{Y}(\mathrm{NP})$ & 0,412 & 0,015 & - & 0,000 & Didukung \\
\hline $\mathrm{H}_{1 \mathrm{a}}$ & $\mathrm{X}_{1}(\mathrm{DD}) \rightarrow \mathrm{Y}(\mathrm{NP})$ & 0,022 & 0,022 & - & 0,000 & Didukung \\
\hline $\mathrm{H}_{1 \mathrm{~b}}$ & $\mathrm{X}_{2}(\mathrm{DKI}) \rightarrow \mathrm{Y}(\mathrm{NP})$ & 0,553 & 0,553 & - & 0,000 & Didukung \\
\hline $\mathrm{H}_{1 \mathrm{c}}$ & $\mathrm{X}_{3}(\mathrm{DKNI}) \rightarrow \mathrm{Y}(\mathrm{NP})$ & 0,047 & 0,047 & - & 0,0035 & Didukung \\
\hline $\mathrm{H}_{2}$ & $\mathrm{X}(\mathrm{BZ}) \rightarrow \underset{(\mathrm{NP})}{\mathrm{M}(\mathrm{MAN}) \rightarrow \mathrm{Y}}$ & - & 0,0019 & $\begin{array}{c}1,031< \\
1,96\end{array}$ & - & $\begin{array}{l}\text { Tidak } \\
\text { didukung }\end{array}$ \\
\hline $\mathrm{H}_{2}$ & $\mathrm{X}_{1}(\mathrm{DD}) \rightarrow \underset{(\mathrm{NP})}{\mathrm{M}(\mathrm{MAN})} \rightarrow \mathrm{Y}$ & - & 0,018 & $\begin{array}{c}-0,4044< \\
1,96\end{array}$ & - & $\begin{array}{c}\text { Tidak } \\
\text { didukung }\end{array}$ \\
\hline $\mathrm{H}_{2}$ & $\begin{aligned} \mathrm{X}_{2}(\mathrm{DKI}) & \rightarrow \mathrm{M}(\mathrm{MAN}) \\
(\mathrm{NP}) & \rightarrow \mathrm{Y}\end{aligned}$ & - & 0,072 & $\begin{array}{c}-1,295< \\
1,96\end{array}$ & - & $\begin{array}{c}\text { Tidak } \\
\text { didukung }\end{array}$ \\
\hline $\mathrm{H}_{2}$ & $\begin{array}{c}\mathrm{X}_{3}(\mathrm{DKNI}) \rightarrow \mathrm{M}(\mathrm{MAN}) \rightarrow \\
\mathrm{Y}(\mathrm{NP})\end{array}$ & - & 0,038 & $\begin{array}{c}0,686< \\
1,96\end{array}$ & - & $\begin{array}{c}\text { Tidak } \\
\text { didukung }\end{array}$ \\
\hline $\mathrm{H}_{3}$ & $\mathrm{X}(\mathrm{BZ}) \rightarrow \mathrm{M}(\mathrm{MAN})$ & 0,148 & 0,148 & - & 0,91 & $\begin{array}{c}\text { Tidak } \\
\text { didukung }\end{array}$ \\
\hline $\mathrm{H}_{3 \mathrm{a}}$ & $\mathrm{X}_{1}(\mathrm{DD}) \rightarrow \mathrm{M}(\mathrm{MAN})$ & 4,087 & 0,274 & & 0,324 & $\begin{array}{l}\text { Tidak } \\
\text { didukung }\end{array}$ \\
\hline $\mathrm{H}_{3 b}$ & $\mathrm{X}_{2}(\mathrm{DKI}) \rightarrow \mathrm{M}(\mathrm{MAN})$ & 4,087 & 0,900 & & 0,039 & Didukung \\
\hline $\mathrm{H}_{3 \mathrm{c}}$ & $\mathrm{X}_{3}(\mathrm{DKNI}) \rightarrow \mathrm{M}(\mathrm{MAN})$ & 4,087 & 0,551 & & 0,213 & $\begin{array}{l}\text { Tidak } \\
\text { didukung }\end{array}$ \\
\hline $\mathrm{H}_{4}$ & $\mathrm{M}(\mathrm{MAN}) \rightarrow \mathrm{Y}(\mathrm{NP})$ & & & & & \\
\hline & : data diolah (2017) & & & \multicolumn{3}{|c|}{$\begin{array}{l}\text { DD: Dewan Direksi. DKI: } \\
\text { Independen. MAN: Manajemen }\end{array}$} \\
\hline
\end{tabular}

Dewan direksi berpengaruh positif pada nilai perusahaan dengan koefisien regresi sebesar 0,022 dan nilai P-Value sebesar 0,000. Hal ini menunjukkan bahwa semakin banyak personel dalam dewan direksi maka nilai perusahaan juga akan ikut meningkat. Hal ini berarti penambahan 1 (satu) personel dalam dewan direksi akan menyebabkan pengambilan keputusan dalam suatu perusahaan menjadi efektif. Banyaknya anggota pada dewan direksi tentu akan terdapat 
pemikiran dan saran-saran yang banyak pula sehingga dapat dengan mudah untuk mengambil keputusan.

Dewan komisaris independen berpengaruh positif pada nilai perusahaan dengan koefisien regresi sebesar 0,553 dan nilai P-Value sebesar 0,000. Ini berarti bahwa semakin besar jumlah personel dewan komisaris independen dalam suatu perusahaan maka nilai perusahaan juga akan meningkat. Hal ini berarti keberadaan dewan komisaris independen sangat mempengaruhi nilai perusahaan dilihat dari tingkat signifikansi yang dihasilkan. Penambahan satu anggota dewan komisaris independen pada suatu perusahaan berarti semakin bertambahnya pengawasan yang dilakukan pihak eksternal sehingga pasar merespon positif dan dapat mempengaruhi nilai perusahaan.

Dewan komisaris non independen berpengaruh positif pada nilai perusahaan dengan koefisien regresi sebesar 0,047 dan nilai P-Value sebesar 0,0035. Hal ini menunjukkan bahwa semakin banyak personel dalam suatu dewan komisaris non independen maka akan meningkatkan nilai perusahaan. Hal ini berarti supervisi pada perusahaan yang ada di Indonesia masih dianggap perlu sehingga dengan penambahan satu orang personel dewan komisaris non independen akan direspon positif oleh pasar dan akan meningkatkan nilai perusahaan.

Pada hasil perhitungan uji Sobel seperti yang ditunjukkan $\mathrm{H}_{2}$ Tabel 6 diperoleh nilai t hitung board size 1,031, dewan direksi -0,4044, dewan komisaris independen -1,295, dan dewan komisaris non independen sebesar 0,686 lebih kecil dari nilai t Tabel sebesar 1,96. Maka dapat disimpulkan bahwa koefisien mediasi (intervening) tidak signifikan yang berarti bahwa variabel manajemen 
laba tidak mampu memediasi hubungan antara board size (dewan direksi, dewan komisaris independen dan dewan komisaris non independen) dengan nilai perusahaan.

Tabel 7 menunjukkan bahwa variabel board size tidak berpengaruh pada manajemen laba dengan koefisien regresi sebesar 0,148 dan P-Value 0,91. Ini berarti bahwa jumlah dewan dalam suatu perusahaan tidak mampu menjamin keefektifan dalam menjalankan fungsi monitoring pada kinerja manajemen (Widyati, 2013). Dewan tidak memiliki kemampuan untuk mengendalikan manajemen untuk meminimalisir praktik manajemen laba. Besar kecilnya ukuran dewan tidak dapat menjadi faktor penentu utama dari efektivitas pengawasan terhadap manajemen perusahaan, namun tergantung pada efektivitas pengendalian melalui nilai, norma dan kepercayaan yang diterima dalam suatu organisasi serta peran dewan komisaris dalam aktivitas pengendalian (monitoring) terhadap manajemen.

Pada tabel 7 ditunjukkan bahwa bagian dari board size yang menyebabkan variabel board size menjadi tidak signifikan adalah variabel dewan direksi dan dewan komisaris non independen sedangkan variabel komisaris independen menunjukkan pengaruh negatif pada manajemen laba. Dewan direksi tidak berpengaruh pada variabel manajemen laba. Hal ini berarti penambahan satu orang anggota pada dewan direksi maka manajemen laba juga akan menurun. Pada Tabel 7 diketahui bahwa variabel dewan komisaris independen berpengaruh negatif pada manajemen laba dengan koefisien regresi sebesar 0,900 dan P-Value 0,039. Ini berarti penambahan satu orang anggota pada dewan 
komisaris independen akan mengurangi terjadinya manajemen laba. Secara umum dewan komisaris independen memiliki pengawasan yang lebih baik pada manajer sehingga mampu mempengaruhi kemungkinan penyimpangan yang dilakukan manajer. Hal ini sesuai dengan pendapat Jensen dan Meckling (1976) yang menyebutkan bahwa teori keagenan mendukung pernyataan bahwa untuk meningkatkan independensi dewan, maka dewan harus didominasi oleh pihak yang berasal dari luar perusahaan (outsider). Tabel 7 juga menunjukkan bahwa dewan direksi dan dewan komisaris non independen tidak berpengaruh pada manajemen laba. Hal ini berarti menunjukkan ketidakmampuan dari anggota dewan dalam meminimalisir terjadinya manajemen laba.

Variabel manajemen laba berpengaruh negatif pada nilai perusahaan dengan koefisien regresi sebesar 0,006 dan nilai P-Value sebesar 0,013. Hal ini berarti bahwa peningkatan yang terjadi pada praktik manajemen laba akan menurunkan nilai suatu perusahaan. Praktik manajemen laba dinilai merugikan karena dapat menurunkan nilai laporan keuangan dan memberikan informasi yang tidak relevan bagi investor (Darwis, 2009).

\section{SIMPULAN DAN SARAN}

Berdasarkan hasil pengujian empiris dan pembahasan dapat disimpulkan bahwa: 1) Board size berpengaruh positif pada nilai perusahaan. Board size yang diproksikan dengan dewan direksi, dewan komisaris independen dan dewan komisaris non independen ketika diuji pada nilai perusahan memperoleh hasil sebagai berikut: (a) dewan direksi berpengaruh positif pada nilai perusahaan, (b) 
dewan komisaris independen berpengaruh positif pada nilai perusahaan, (c) dewan komisaris non independen berpengaruh positif pada nilai perusahaan. 2) Manajemen laba tidak mampu memediasi hubungan antara board size dengan nilai perusahaan. 3) Board size tidak berpengaruh pada manajemen laba. Board size yang diproksikan dengan dewan direksi, dewan komisaris independen dan dewan komisaris non independen ketika diuji pada manajemen laba memperoleh hasil sebagai berikut: (a) dewan direksi tidak berpengaruh pada manajemen laba, (b) dewan komisaris independen berpengaruh negatif pada manajemen laba, (c) dewan komisaris non independen tidak berpengaruh pada manajemen laba. 4) Manajemen laba berpengaruh negatif pada nilai perusahaan.

Keterbatasan pada penelitian ini adalah rentang waktu penelitian yang digunakan hanya selama empat tahun sejak tahun 2012-2015. Perusahaan yang digunakan juga terbatas pada perusahaan manufaktur sehingga tidak bisa digunakan untuk menyimpulkan hasil jika menggunakan perusahaan lain selain manufaktur. Variabel nilai perusahaan pada penelitian ini diproksikan dengan menggunakan PBV. Sedangkan, berdasarkan penelitian-penelitian yang lain, nilai perusahaan juga dapat diproksikan dengan tobinsQ atau Price to Earnings Ratio (PER).

Hasil penelitian ini memberikan tambahan bukti empiris mengenai pengaruh board size pada nilai perusahaan dengan manajemen laba sebagai variabel intervening yang diukur dengan PBV serta dikontrol dengan variabel struktur pendanaan, profitabilitas, usia perusahaan dan komite audit. Selain itu digunakan juga manajemen laba yang diukur dengan diskresionari akrual sebagai 
variabel intervening, sehingga dapat mencerminkan penilaian investor atas setiap ekuitas yang dimiliki perusahaan. Beberapa saran yang dapat diberikan meliputi: 1) bagi perusahaan, perusahaan manufaktur yang terdaftar di Bursa Efek Indonesia agar meningkatkan nilai perusahaan dengan memperhatikan jumlah dewan direksi, komisaris independen, dan komisaris non independen. Dengan adanya faktor-faktor dari board size tersebut maka nilai perusahaan akan mampu berjalan dengan maksimal karena adanya pengawasan yang cukup ketat dan praktik manajemen laba juga akan berkurang sehingga dapat meningkatkan nilai perusahaan. 2) bagi investor, disarankan bagi investor sebelum menginvestasikan dananya dapat terlebih dahulu mengetahui perkembangan nilai perusahaan yang dapat dilihat dari board size (dewan direksi, dewan komisaris independen, dewan komisaris non independen) dan manajemen laba. Hal itu dimaksudkan sejauh mana efektivitas pengawasan yang dilakukan untuk meminimalkan terjadinya manajemen laba sehingga dapat meningkatkan nilai perusahaan. 3) bagi peneliti, disarankan agar (a) hasil penelitian dapat digunakan secara umum dan luas, maka subjek penelitian pada penelitian selanjutnya diharapkan tidak terbatas hanya pada perusahaan manufaktur yang terdaftar di Bursa Efek Indonesia, namun dapat menggunakan perusahaan sektor lain, (b) menambah atau mencari faktor - faktor lain yang dapat berpengaruh pada nilai perusahaan seperti: ukuran perusahaan, Corporate Social Responsibility (CSR), struktur kepemilikan, kinerja keuangan, keputusan pendanaan dan kebijakan dividen.

\section{REFERENSI}


Barnhart, Scott W. dan Stuart Rosenstein. 1998. Board composition, managerial ownership, and firm performance: An empirical analysis. The Financial Review. Vol. 33 No. 4: p. 1-16.

Baron, R. M., dan Kenny, D. A. 1986. The Moderator-Mediator Variable Distinction in Social Psychological Research: Conceptual, Strategic, and Statistical Considerations. Journal of Personality and Social Psychology. Vol. 51 No. 6: p. $1173-1182$.

Chaganti, R. S., Vijay Mahajan, Subhash Sharma. 1985. Corporate Board, Composition and Corporate Failures in The Retailing Industry. Journal of Management Studies. Vol. 22 No. 4: p. 400-417.

Choi, J.J., Sae, W. P., dan Sean, S.Y. 2007. The Value of Outside Directors: Evidence from Corporate Governance Reform from Korea. Journal of Financial and Quantitative Analysis. Vol. 42 No. 4: p. 941-962.

Dahya, J., Dimitrov, O., dan McConnell, J.J. 2007. Dominant Shareholders, Corporate Boards, and Corporate Value: A Cross-Country Analysis. Journal of Financial Economics. Vol. 87 No.1: p. 73-100.

Dalton, DR, Daily, CM, Johnson, JL dan Ellstrand, AE. 1999. Number of directors and financial performance: A meta-analysis. Academy of Management Journal. Vol. 42 No. 6: p. 674-686.

Darwis, Herman. 2009. Corporate Governance terhadap Kinerja Perusahaan. Jurnal Keuangan dan Perbankan. Vol. 13 No. 3. p. 418- 430.

Dechow, P.M, Sloan, R.G, Sweeney A.P. 1996. Causes and Consequences of Earnings Manipulation: An Analysis of Firms Subject To Enforcement Actions by The SEC. Contemporary Accounting Research. Vol. 13 No. 1: p. 1 - 36.

Egon Zehnder International. 2000. Corporate Governance and the Role of The Board of Directors.

Foster, George. 1986. Financial Statement Analysis, Second Edition, Englewood Cliffs, New Jersey: Prentice-Hall, A Division of Simon \& Schuster, Inc.

Ghosh, A., A. Marra, dan D. Moon. 2010. Corporate Boards, Audit Committees, and Earnings Management: Pre-and Post-SOX Evidence. Journal of Business Finance \& Accounting. Vol. 37 No. 9 \& 10: p. 1145-1176.

Ghozali, Imam. 2006. Aplikasi Analisis Multivariate Dengan Program SPSS. Semarang: Badan Penerbit Universitas Diponegoro.

Ghozali, Imam. 2012. Aplikasi Analisis Multivariate dengan Program SPSS. Badan Penerbit Universitas Diponegoro: Semarang. 
Hariyanto, Lidia. 2014. Pengaruh Family Control, Firm Risk, Firm Size dan Firm Age terhadap Profitabilitas dan Nilai Perusahaan pada Sektor Keuangan. Business Accounting Review. Vol 2 No.1: p. 141-150.

Herawaty, Vinola. 2009. Peran Praktek Corporate Governance Sebagai Moderating Variable dari Pengaruh Earnings management Terhadap Nilai Perusahaan. Jurnal Akuntansi dan Keuangan. Vol. 10 No. 2: p. 97.

Hermansyah, Ade Raya, dan Aulia Fuad Rahman. 2012. Pengaruh Good Corporate Governance, Pertumbuhan Penjualan, Dan Pertumbuhan Total Aset Terhadap Nilai Perusahaan. Jurnal Ilmiah Mahasiswa FEB. Vol. 1 No. 2: p. 1-10 .

Hidayati, Eva Eko. 2010. "Analisis pengaruh DER, DPR, ROE dan SIZE terhadap PBV perusahaan manufaktur yang listing di BEI periode 2005-2007” (Dissertasi). Universitas Diponegoro.

Isshaq, Z., G. A. Bokpin, dan J. M. Onumah. 2009. Corporate Governance, Ownership Structure, Cash Holdings, and Firm Value on The Ghana Stock Exchange. The Journal of Risk Finance. Vol. 10 No. 5: p. 488-499.

Jensen, Michael C. dan W.H. Meckling. 1976. Theory of The Firm: Managerial Behavior, Agency Cost and Ownership Structure. Journal of Financial Economics. Vol. 3 No. 4: p. 305-360.

Kusumajaya, Dewa Kadek Oka. 2011. "Pengaruh Usia Perusahaan dan Pertumbuhan Perusahaan terhadap Usia Perusahaan dan Nilai Perusahaan pada Perusahaan Manufaktur di Bursa Efek Indonesia” (Tesis).

Kusumawati, Dwi Novi dan Riyanti, LS Bambang. 2005. Corporate Governance dan Kinerja: Analisis Pengaruh Compliance Reporting dan Struktur Dewan terhadap Kinerja. SNA VIII Solo. p. 248 - 261.

Martono dan Agus Harjito. 2010. Manajemen Keuangan. Cetakan kedelapan. Yogyakarta: Ekonisia.

Mat Nor, Fauzias dan Zunaidah Sulong. 2008. Dividends, Ownership Structure and Board Governance on Firm Value: Empirical Evidence from Malaysian Listed Firms. Malaysian Accounting Review. Vol. 7 No 2: p. 55 - 94.

Nasution, Marihot, dan Doddy Setiawan. 2007. Pengaruh Corporate Governance terhadap Manajemen Laba di Industri Perbankan Indonesia. Simposium Nasional Akuntansi X. p. 1-20.

Nazir, Moh. 2011. Metode Penelitian. Cetakan Ketujuh. Ghalia Indonesia: Bogor. Nugroho, Bernardus Y., dan P. Umanto Eko. 2011. Board Characteristics and Earnings Management. Bisnis \& Birokrasi Journal. Vol. 18 No. 1: p. $1-10$. 
A.A Pt. Agung Mirah Purnama Sari, Ni Ketut Rasmini dan I Gst Ayu Nyoman Budiasih., Pengaruh....

Preffer. J. dan G.R. Salancik . 1978. The External Control of Organizations: A Resource Dependence Perspective. New York: Harper \& Row.

Reilly, Frank K., dan Keith C. Brown. 2000. Investment Analysis and Portfolio Management. Six Edition. The Drryden Press, USA.

Stoner, James A.F; Freeman, R, Edward; Gilbert JR, Daniel , R. 1996. Manajemen. Jilid I. PT. Bhuana Ilmu Populer.

Studenmund, A. H. 2006. Using Econometrics: A Practical Guide. Fifth Edition. Pearson Education, Inc.

Sudarmadji M, Ardi, dan Lana Sularto. 2007. Pengaruh Ukuran Perusahaan, Profitabilitas, Leverage, dan Tipe Kepemilikan Perusahaan terhadap Luas Voluntary Disclosure Laporan Keuangan Tahunan. Seminar Ilmiah Nasional PESAT 2007. Lembaga Penelitian Universitas Gunadarma. ISSN: 1858 - 2559. Vol. 2 No. 1: p. A53 - A61.

Trisnantari, A. N. 2010. Pengaruh Corporate Governance pada Hubungan Pergantian Chief Executive Officer dengan Kinerja Perusahaan. Tesis.

Walsh, Ciaran. 1996. Key Management Ratios. London: Prentice Hall.

Wardjono. 2010. Analisis Faktor-faktor yang Mempengaruhi Price to Book Value dan Implikasinya pada Return Saham. Dinamika Keuangan dan Perbankan. Vol. 2 No. 1: p. 83 - 96.

Watts, Ross L., dan J L Zimmerman. 1986. Positive Accounting Theory. New Jersey: Prentice-Hall, Inc.

Widyati, Maria. F. 2013. Pengaruh Dewan Direksi, Komisaris Independen, Komite Audit, Kepemilikan Manajerial dan Kepemilikan Institusional terhadap Kinerja Keuangan. Jurnal Ilmu Manajemen. Vol. 1. No. 1: p. 234-249. 